\title{
THE ASSOCIATION BETWEEN HEALTH LITERACY, FAMILY SUPPORT, AND THE RECURRENCE OF SCHIZOPHRENIA IN KEDIRI, EAST JAVA
}

\author{
Agustin Widyowati'1,2), Bhisma Murti3), Aris Sudiyanto4), Suminah2) \\ 1)School of Health Sciences Ganesha Husada, Kediri, East Java \\ 2)Doctoral Program in Community Development and Empowerment, \\ Universitas Sebelas Maret \\ 3) Masters Program of Public Health, Universitas Sebelas Maret \\ 4)Department of Psychiatric Faculty of Medicine, Universitas Sebelas Maret
}

\begin{abstract}
Background: Schizophrenia is a psychotic disorder that has become an important global public health problem. In Indonesia, the prevalence of schizophrenia remains high, reaching 1-2 per 1000 population. Many factors may affect the recurrence of schizophrenia which include family health literacy and family support. This study aimed to examine the association between health literacy, family support, and the recurrence of schizophrenia in Kediri, East Java. Subjects and Method: This was an analytic observational study with a crosssectional design. A sample of 106 families who had family members with schizophrenia was selected for this study by purposive sampling. The dependent variable was schizophrenic recurrence. The independent variables were health literacy and family support. The data were collected by questionnaire and analyzed by logistic regression.

Results: The recurrence of schizophrenia increased with low health literacy $(\mathrm{OR}=4.76$; CI $95 \%=1.60$ to $14.17 ; \mathrm{p}=0.005)$ and poor familly support $(\mathrm{OR}=$ 17.92; CI 95\%= 5.77 to $55.60 ; \mathrm{p}<0.001$ ).

Conclusion: The recurrence of schizophrenia increases with low health literacy and poor familly support.
\end{abstract}

Keywords: schizophrenia, recurrence, health literacy, family support

\section{Correspondence:}

Agustin Widyowati. School of Health Sciences Ganesha Husada, Kediri, East Java. Mobile: 085735399728.

Mid-International Conference on Public Health, Best Western Premier Hotel, Solo, Indonesia, 18-19 April 2018 | 249 https://doi.org/10.26911/mid.icph.2018.05.11 